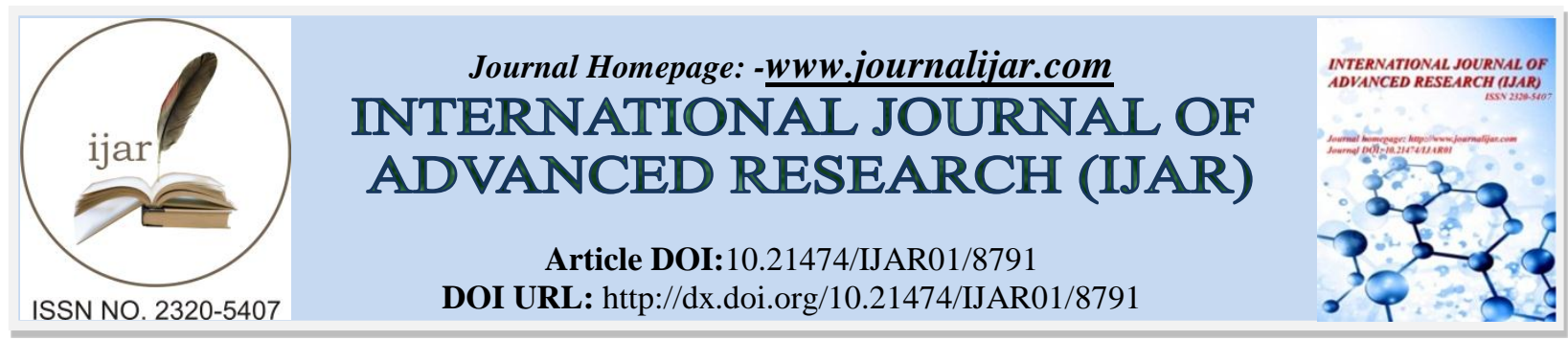

RESEARCH ARTICLE

\title{
RETIREMENT AS A VARIATION PROCESS OF THE PSYCHO-AFFECTIVE SCOPE OF THE ELDERLY.
}

\author{
Melissa Noemí Itzá Canché ${ }^{1}$, Iván Israel Be González ${ }^{1}$, Ana Rosa Can Valle² and Jaqueline Guadalupe \\ Guerrero $\mathrm{Ceh}^{2}$.
}

1. Intern of the degree in gerontology at the Faculty of Nursing at the Autonomous University of Campeche.

2. Professor and Researcher at the Faculty of Nursing at the Autonomous University of Campeche.

\section{Manuscript Info}

\section{Manuscript History}

Received: 03 February 2019

Final Accepted: 05 March 2019

Published: April 2019

\begin{abstract}
According to Cotalero, A, (2015) a person who enters the retirement process begins again to fulfill a role that he / she stopped playing and in this way his/her lifestyle changes in an abrupt way and if he / she is not well oriented in this process he / she is affected in his occupational status, such that if an older adult does not receive adequate preretirement training, when experiencing this change, his life is affected and can be manifested in a positive and healthy way, but it can also be useful to see how you can see in a great way in your quality of life, for the reason of having completed a great stage in your life of many years without proper preparation.Objective: Describe repercussions that generates retirement in the psycho-affective area of the elderly. Method: The investigation has a descriptive design with a qualitative approach. Society: 30 older people of two institutions. Instrument: Geriatric Depression Scale Yesavage; Questionnaire for "valuation of leisure activities and free time; Life Satisfaction Index (LSI-A). Results: There are a total of 13 older adults in a state of depression, and 17 in a normal state; in the questionnaire of the valuation of leisure and free time activities, we obtained an amount of 10 elderly people who are currently inactive while 20 who are currently active; The Vital Satisfaction Index that was obtained from the IMSS sample shows that 9 people do not feel satisfied with their life (dissatisfaction), while the remaining group of 21 Older Adults according to the index, have a satisfactory mentality regarding their life (satisfaction). Conclusions: Older adults who have an adequate pre-retirement orientation, experience no psycho-affective changes that become harmful or damage the quality of life of the elderly, Whether if the individual finding in the process of transition to retirement or has gone through the post-employment process.
\end{abstract}

Copy Right, IJAR, 2019,. All rights reserved.

\section{Introduction:-}

It is very important to have in mind that the role played by an adult citizen who at the moment of being active at work tends to have a greater weight in the person's role as worker, for which, and according to Cotalero, A, (2015) a

Corresponding Author:-Melissa Noemí Itzá Canché.

Address:-Intern of the degree in gerontology at the Faculty of Nursing at the Autonomous University of 61 Campeche. 
person who enters the retirement process begins again to fulfill a role that he / she stopped playing and in this way his lifestyle changes in an abrupt way and if he / she is not well oriented in this process he / she is affected in his occupational status, such that if an older adult does not receive adequate pre-retirement training, when experiencing this change, his life is affected and can be manifested in a positive and healthy way, but it can also be caused that his quality of life is greatly affected by the reason to have culminated a great stage in his life of many years without proper preparation. Barcé, (2015) in his work "Between work and retirement: The old age" Affirms the following: it is necessary to know the ideas, motivations and expectations on the part of the officials regarding the moment of leaving the job. The social stereotypes that link old age to a stage of decline are enhanced by understanding retirement as a passive stage, versus the active stage of working life, making it difficult to rebuild a life project (page 3). When you are working, a routine is generated that, over the years, happens to be part of our life and it becomes normal to go through certain activities every day, but what should not be forgotten is that being part of the elderly, this routine is very difficult to assimilate and eliminate from the person, which is why it is affected. The retired elderly are more prone to fall into depression and as Llanes Torres H.M., López Sepulveda Y., and Vázquez Aguilar J.L. (2015) say, it is necessary to study the depression, as one of the affective processes that are damaged with increasing age, combining multiple factors.

Since there are abrupt changes in their life both socially and economically, this is going to border on maintaining a mostly negative mentality towards society and towards oneself, if this event is not properly channelled. It can be important in the case of depression. That is why it is essential to identify how retirement affects the retired senior citizen, since the knowledge of how it affects can be achieved to counteract these risk factors and promote emotional integrity of older adults who are already retired or are about to retire.

\section{Social relevance.}

It is essential that a senior citizen, once he has retired, receives the proper orientation and, if possible, that orientation is given in a certain time before he stops working, because in this way they do not feel an abrupt change in their lives when they stop playing a certain role in society, since as retirement is a neglect of a certain role, if it is not carried out or routed well later, older adults do not generate a need to build a role, (Biancotti et al., 2001, Tellez Rivera \& Reyes Montoya, 2004 ).

\section{Practical implications.}

According to Adalberto and Maritza (2017), the identification of factors that provide guidelines for the management of the health care of the worker during his retirement would encourage an effective participation in their education and instruction, making this period a positive event with results oriented to strengthening the biopsychosocial health of the elderly in the retirement phase. Knowing all the negative consequences that generate inadequate preparation for retirement, it is fundamental because when dealing with it, it is possible to prevent certain factors that promote isolation, depression and abandonment as Valentina Ferrari (2015) mentions that the elderly must be conceived from a new paradigm: as a desiring and autonomous subject, capable of being projected to the future and to reinvent themselves daily in a creative act of their identity.

\section{Retirement phases.}

According to Atchley, (1989) the retirement process includes some aspects such as:

1. Pre-retirement phase. Approach expectations about retirement and achievable objectives. The attitude has an impact.

2. Phase of the honeymoon. Try to do everything you want and you could not or the activity is decreased.

3. Disenchantment phase. Faced with the non-fulfillment of expectations, the person feels that something is missing. Or perform an excess of activities and exhaust or feel useless without having to produce anything.

4. Reorientation phase. More realistic expectations about retirement are formed until an adjustment is made between perceptions and reality. The person's approach about to how they want to this pass life stage.

5. Stability phase. Adjustment to a predictable routine.

\section{Attitudes before retirement.}

"Rejection" involves a denial in retirement. It happens in situations of significant development or overvaluation of work activity. There are cases of rejection in early retirement since it is a sharp distancing of the career; by the passivity that implies or by its association with aging. Research has found that there is greater rejection the higher the educational level, the emotional attachment to work activity and satisfaction with their performance (Saez-Narro, Aleixandre and Martinez-Arias, 1996). 
"Acceptance" shows conformity with the stage that must be faced and that is inevitable. This attitude has become typical of people of medium and low status. "Release", the person considers it as a reward for the work done. There is a risk in this attitude and it leads to boredom and apathy inasmuch as there are lack of expectations, projects and activities to fill the time that previously occupied the work activity.

"Opportunity", implies a wish of the person to retire since there is the possibility of undertaking projects and activities that, so far for work reasons, they would not occur such as: volunteering, leisure time, social relations, travel, new learnings, etc. It is a positive vision of retirement that allows you to start new activities that can be more enriching than the work that was done previously.

"Ambivalence", several attitudes of the previous ones can appear jointly. Different discourses can be found in the same person in different ways since it depends on different aspects. There are other psychosocial factors that also affect the state of health since it can advance or delay work retirement or favor or limit the carrying out of activities and social contacts (Iglesias, 2001).

\section{Effects of retirement.}

The effect is a complex process that begins before retirement, coping and adaptation and continues until it is overcome. The duration will depend on the situational context in which this process occurs. The effects can be:

\section{Positive:}

greater disposition of free time, greater dedication to the family, lower level of stress associated with work tensions, feeling of freedom, recreational use of free time, possibility of developing hobbies and potential.

\section{Negative:}

reduction of income, reduction of goals and activities, decrease in the ability to make decisions, less development of personal abilities, increase of insecurity in the future, loss of interpersonal relationships, appearance of conflicts with the couple, loss of social position, loneliness, depression, anxiety.

\section{Method:-}

The research has a descriptive design with a qualitative approach, since subjective aspects of people will be measured retired and so identify the repercussions that these have brought to their lives, whether positive or negative. Instrument: Geriatric Depression Scale Yesavage. Spanish version, short, has 15 items with affirmative and negative answers.

Questionnaire for "valuation of leisure and free time activities", to identify how the person uses their time for their good. Life Satisfaction Index (LSI-A). The adaptation to retirement and its phases: affectation of satisfaction levels and duration of the adaptive process.

\section{Procedure:-}

The data that is collected for this investigation, will be taken through surveys that will be implemented to 30 seniors people from 55 to 69 years of age who worked in formal jobs and / or retirement and come consult in a social network or in a location that offers a space of recreation and service to people who are retired, so we can see which people have manifested these changes, whether negative or positive but in this way you can identify the most common problems that retired seniors have experienced by and in turn in which gender is more vulnerable to such changes if that were the case. The surveys were applied in the Mexican Institute of Social Security (IMSS) and in the National Institute for Older Persons (INAPAM). First they were offered an explanation of what the investigation consisted and if they agreed they signed the informed consent letter and they answer the questionnaires, and then the data is processed through the Microsoft Excel program.

\section{Results:-}

Regarding the scale of Yesavage Geriatric Depression (table 1), there are a total of 13 older adults in a state of depression (graph 1) and 17 in a normal state (graph 2). Taking into account gender, there are more women in a state of depression. It should be noted that when performing a sectorization of the population, INAPAM had 5 cases of older adults with depression, while the IMSS with 8 cases shows us that it is a vulnerable group to suffer the state of depression due to the lack of activity and the free time that they have wasted. 
Table 1:-Depression / Normal State (Yesavage depression scale).

\begin{tabular}{|l|l|l|l|l|}
\hline \multicolumn{2}{|l|}{} & NORMAL STATE & DEPRESSION STATE \\
\hline Institution & Man & Women & Man & Women \\
\hline INAPAM & 4 & 6 & 1 & 4 \\
\hline IMSS & 3 & 4 & 5 & 3 \\
\hline TOTAL & 7 & 10 & 6 & 7 \\
\hline
\end{tabular}

\section{NORMAL PSYCHO-AFFECTIVE STATE}

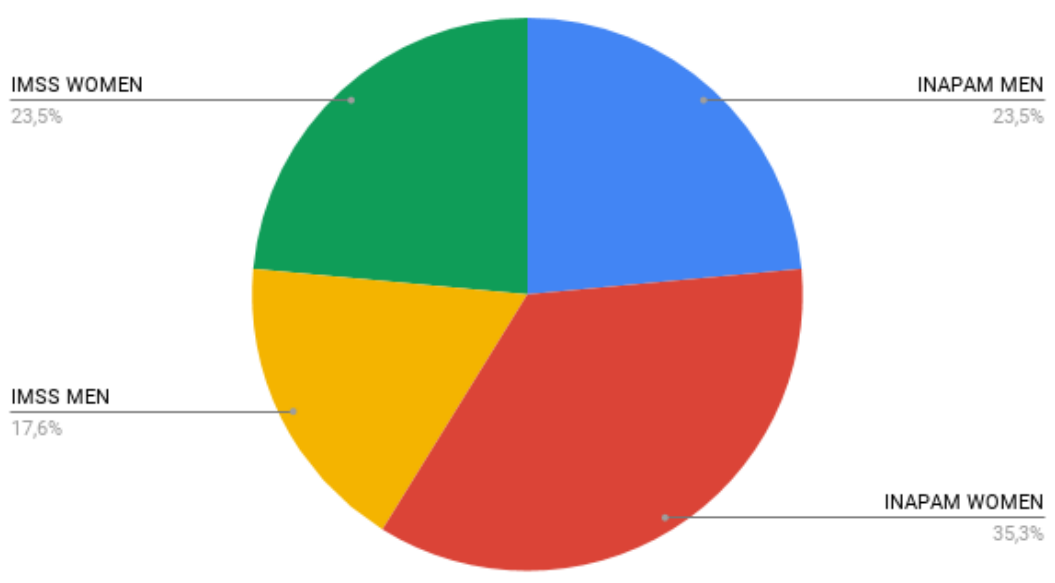

Graph 1:-Normal psycho-affective state

\section{PSYCHO AFFECTIVE STATE WITH DEPRESSION}

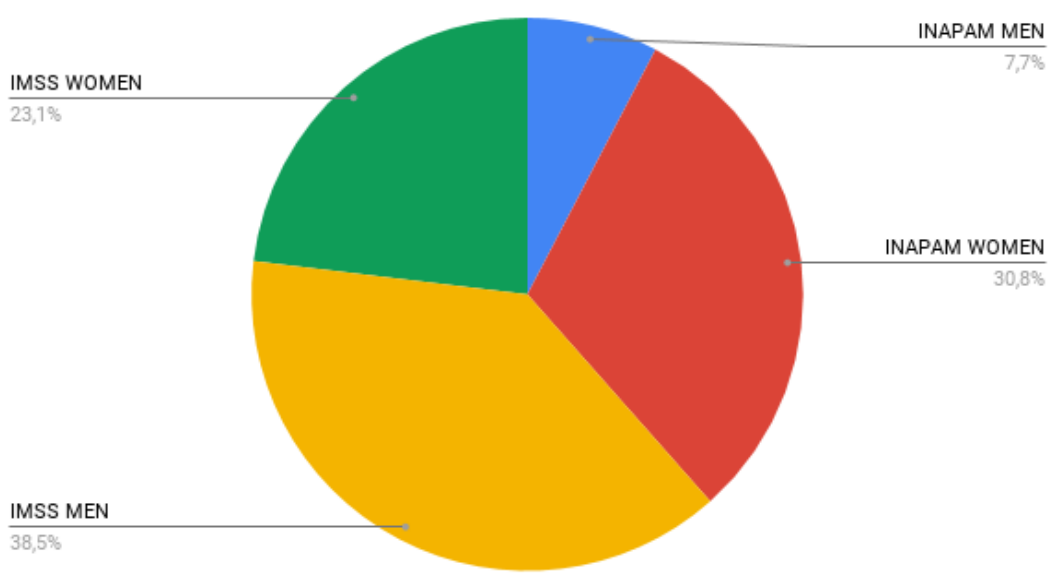

Graph 2:-Psycho-affective state with depression

In the questionnaire for the evaluation of leisure and free time activities, the results indicated 10 elderly people who are currently inactive (figure 4), while 20 are currently active (chart 3). In the INAPAM there were no cases of inactive elderly so all those who were surveyed are participating productively in the institution. On the other, older adults from our sample population who attend their monthly appointments at the IMSS present 10 cases of inactivity. In this case, more men were inactive than women, so even this could lead them to a shorter life expectancy, as shown in Table 2.

Table 2:-Active / Inactive. Questionnaire for assessment of leisure and free time activities

\begin{tabular}{|l|l|l|l|l|}
\hline & \multicolumn{2}{|l|}{ ACTIVE } & \multicolumn{2}{l|}{ INACTIVE } \\
\hline Institution & Man & Women & Man & Women \\
\hline
\end{tabular}




\begin{tabular}{|l|l|l|l|l|}
\hline INAPAM & 5 & 10 & 0 & 0 \\
\hline IMSS & 2 & 3 & 6 & 4 \\
\hline TOTAL & 7 & 13 & 6 & 4 \\
\hline
\end{tabular}

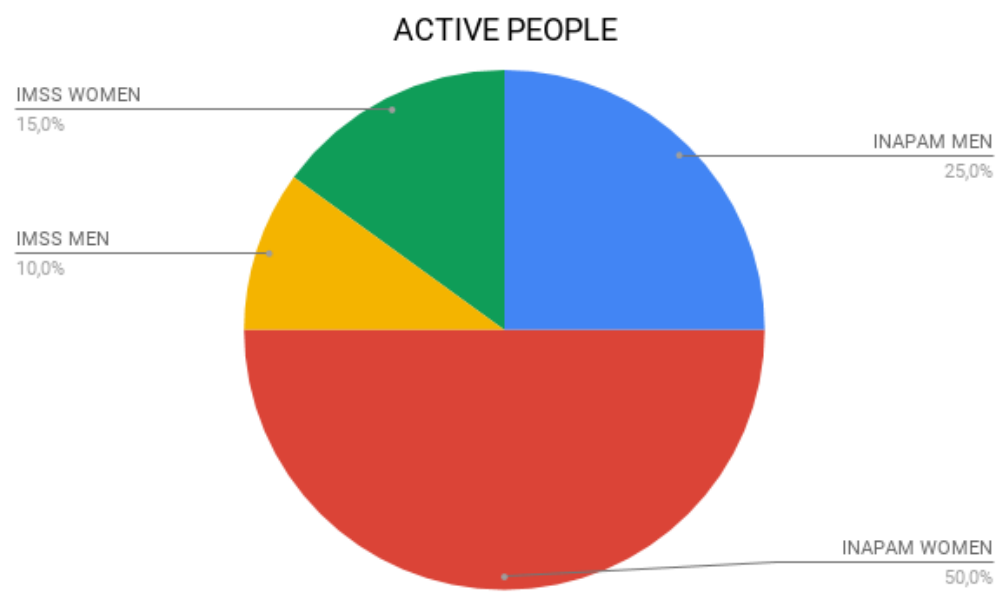

Graph 3:-Active People

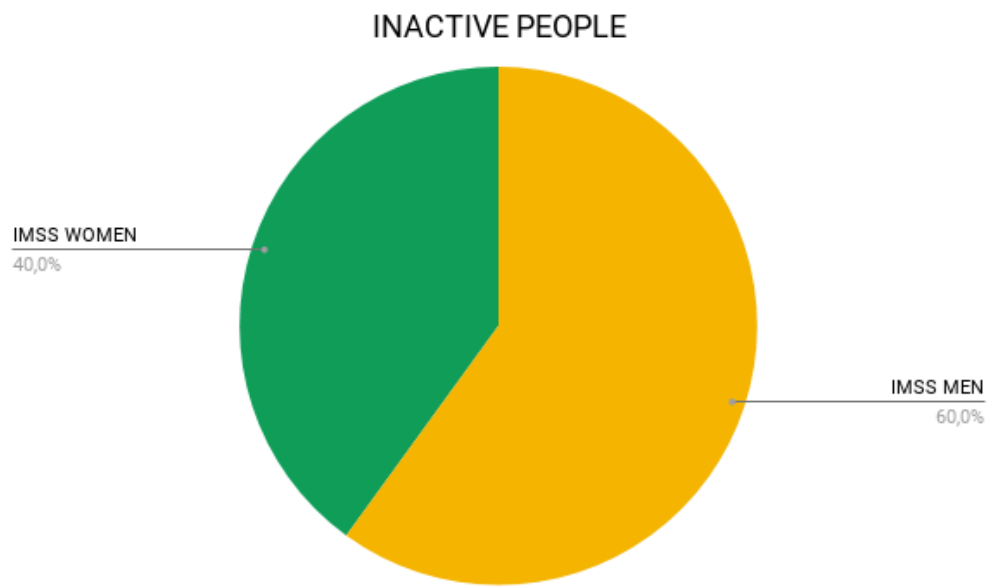

Graph 4:-Inactive People

Regarding the Life Satisfaction Index shown in (Table 3), it was obtained from the IMSS sample that 9 people do not feel satisfied with their life (dissatisfaction) (graph 5), while the remaining group of 21 older adults according to the index, and find a satisfactory mentality regarding their life (satisfaction) (graph 6). In the case of the elderly of the INAPAM there were no unsatisfactory cases according to the results of the index.

Table 3:-Satisfactory / Unsatisfactory. Life Satisfaction Index (LSI-A)

\begin{tabular}{|l|l|l|l|l|}
\hline & \multicolumn{2}{|l|}{ SATISFACTORY } & UNSATISFACTORY \\
\hline Institution & MAN & WOMEN & MAN & WOMEN \\
\hline INAPAM & 5 & 10 & 0 & 0 \\
\hline IMSS & 2 & 4 & 6 & 3 \\
\hline TOTAL & 7 & 14 & 6 & 3 \\
\hline
\end{tabular}




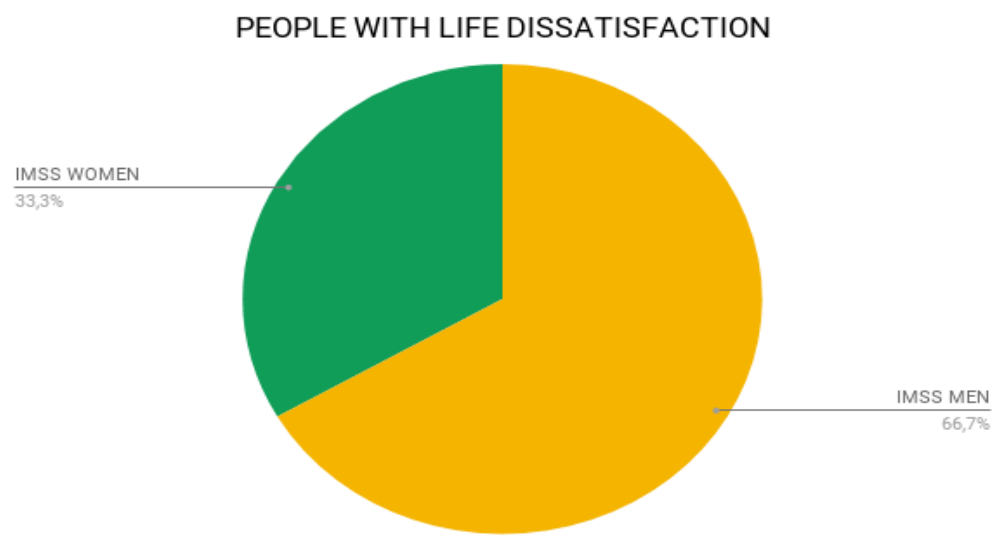

Graph 5:-People with life dissatisfaction

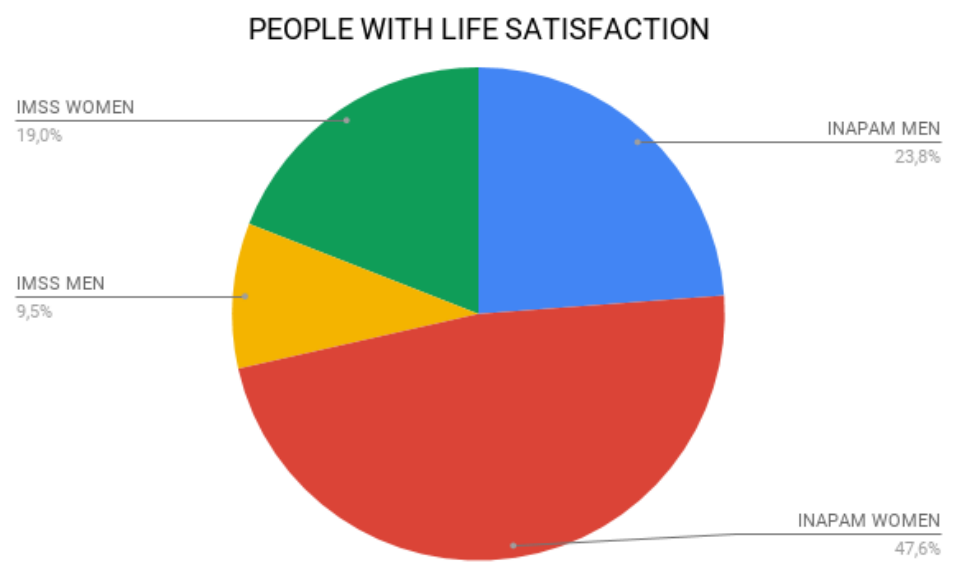

Graph 6:-People with life satisfaction

\section{Conclusions:-}

Seniors properly oriented correlates to better health, better social participation and a positive perspective towards their person and environment, regardless of physical afflictions and family issues that each one suffers. A due and timely intervention by the institutions for their next candidates to retire can initiate a significant difference for them to foment and achieve an adequate active aging, and in this way their performance in the stage of old age is the most appropriate and dignified. Elderly people who are given adequate pre-retirement guidance, do not present psychoaffective changes that are considered harmful or damage the quality of life of the elderly person, whether the individual is in the process of transition to retirement or has already gone through this post-employment process.

\section{Bibliographic references:-}

1. Atchley, R. C. (1989). A continuity theory of normal aging. The Gerontologist, 29, 183-190. DOI: 10.1093/geront/29.2.183 .

2. Aymeich, A. M, Planes, M. P y Gras, P. M. (2010). La adaptación a la jubilación y sus fases: Afectación de los niveles de satisfacción y duración del proceso adaptativo. Anales de Psicología. 1 (26), 80-88. Recuperado de http://www.redalyc.org/articulo.oa?id=16713758010

3. Cotarelo P, A. K. (2015) Cambio de roles en el Adulto Mayor antes y después de la jubilación. TOG (A Coruña) 12 (21), 14. Recuperado de www.revistatog.com/num21/pdfs/original2.pdf

4. Tesis de Grado Final. Barbé C. (2015) Entre el trabajo y la jubilación: La vejez. Universidad de la República, Facultad de Psicología. Montevideo 30 de julio de 2015.

5. Llanes T. H., López S. Y. y Vázquez Aguilar J.L. (2015). Factores psicosociales que inciden en la depresión del Adulto Mayor. Revista de Ciencias Médicas. (1). 65 - 68. Recuperado de http://scielo.sld.cu/scielo.php 
6. Quezada A. C. (2017). Violación al legítimo derecho constitucional de jubilación por vejez, habiendo cumplido con todos los requisitos exigidos por el IESS. Recuperado de https://www.inclusion.gob.ec/wpcontent/uploads/downloads/2012/09/Agendas_ADULTOS.pdf

7. Sánchez, Y. y Rodríguez de la Fuente, J.: "Jubilación, tiempo y vida cotidiana. La (2012). Distribución del tiempo en la vejez desde las representaciones de personas en edad pre jubilatoria", en Contribuciones a las Ciencias Sociales, www.eumed.net/rev/cccss/20. 